\title{
A Paean to Narration, or Narrative Paths of Educating to Values
}

Helena Zbudilová

"If you want to show someone his face and wake him up from sleep, you must clothe his face with stories."

Nachman of Breslov

The present issue of the journal Caritas et Veritas focuses on Values in Education. The theme was chosen for its topicality in cooperation with the Department of Pedagogy of the Faculty of Theology, University of South Bohemia in České Budějovice. It leads the author of this paper to present a manner of reflection specific to the humanities in the sphere of reflecting on the reality of narrated stories. The very title of the text suggests that it does not aim to be a narratological study, but a paper emphasising the importance of narrativity in the pedagogical process. The "Paean to Narration" anticipates the positive flow of the text and the author's identification with "narrative paths", which she understands as one of the paths of educating to values. The text echoes with ideas of selected personalities (especially from the sphere of philosophy, literary science, pedagogy and psychology) bearing on the problem of value crisis in contemporary society and the role of narrativity in relation to value-oriented education. The text emphasizes the positive aspects of "narrative paths" of educating to values because narrating stories has its place in contemporary pedagogical discourse.

\section{Value crisis in contemporary society}

In the post-educational period (a term coined by Radim Palouš) influenced by the spirit of consumerism, which exists across cultures and states, we perceive that the contemporary way of life is lead without intense spiritual and other values. These are disappearing from human life. What prevails are values of material character (utilitarian values) linked with the desire for a high standard of living, money, personal prestige and success. The social and cultural reality is ever more intensively penetrating the sphere of education without respect for the development of the emotional and moral component of personality. Vladimír Spousta in his study The Crisis of Contemporary Society and Value Changes at the Turn of the Millennium recommends intensifying orientation on spiritual values, on ethical and aesthetic questions. ${ }^{1}$ We forget that we are linked to other humans by shared life values and mutuality, so-called co-humanity. ${ }^{2} \mathrm{Jan}$ Patočka said that in postmodernism human beings lack a foothold, something permanent and universally valid. A return to "lived" values by means of "educating to values" could provide such a foothold.

For the world at the beginning of the 3rd millennium the words of Erich Fromm, who described modern society as "technologically oversaturated" ${ }^{3}$ and "humanly undernourished", 
still hold. ${ }^{4}$ Reification of human beings, estranging individualization and depersonalization of human relationships occur. Human beings are being turned into objects under various codes and numbers, even their souls have been reified. Their time is a time of displays and screens, of general virtualization of life as a ceaseless show with omnipresent advertising. In the spirit of orwellization of lifestyle human beings are becoming slaves of cell phones and computers, their lives are overseen by the "Big Brother". In an age of information science and a world of media and the internet being has turned into happening - a vicious circle of work, enjoyment and consumption. ${ }^{5}$ Humans flee from themselves and stun themselves with work and entertainment. The postmodern gnoseological and value relativism and plurality lead to fragmentation and eclecticism. Truth is becoming an empty word, law and justice instruments of differing interpretations. It is a disintegration of values, order, truth, wholes to the benefit of parts. ${ }^{6}$ This time of value crisis (in the extreme form of value and ethical nihilism) is also a crisis of narration. The postmodern pseudo-free human being does not form opinions - she chooses them. According to Jan Poněšický this human being functions in multiple identities, and if she has no ideals, she need not feel guilt or shame for betraying them. ${ }^{7}$ She stylizes herself in the position of spectator, external observer, impartial arbiter. In the spirit of postmodern flexibility the human being is ever capable of retelling her life so far anew. Her illusive world of deformed reality is a world of emptied symbolism and loss of historical consciousness. A world maimed by absence of the sacred, by resignation on both reason and faith. Global insight is missing, specialization reigns over all. Reality is not perceived as a coherent whole, but as "a scrummage of contingent, changeable events". 8 Values are constantly being re-evaluated, which as a result leads to a permanent threat of loss of integrity. Every absolute value can be de-masked as absurd, smacking of totality or disintegrated meta-narration. ${ }^{9}$ Perennial and traditional values are set in doubt and relativized, they often disappear in the flood of tempting offers of life without obligations and responsibility. ${ }^{10}$ Only one unshakable value has remained - the market. The postmodern world which construes values as open structures ever ready to be re-evaluated seems to be fundamentally a resignation on humanity, free choice and free responsibility. ${ }^{11}$ Zygmunt Bauman even expresses fear of the possible future transition from the type of human-gardener to human-hunter. There arises a picture of a human being who has resigned, surviving in the unconcerned emptiness of her being where there is neither God nor fellow human. According to Jan Poněšický "the existential thrownness of the human being into potential absolute freedom linked to anxiety and insecurity is in the contemporary world countercast by its opposite - satisfaction and conviction that no one has the right to prescribe anything, moralize or direct in any way". ${ }^{12}$

\section{Characteristic of narrativity}

Telling stories - narrativity - is a basic way humans relate to reality. Nothing in the world, no human, no thing can be without a story. Narrativization is a process in which humans take

\footnotetext{
4 Ibid., p. 18.

5 Cf. Anna HOGENOVÁ, Postmoderna a fenomenologie, in: Člověk a jeho postavení ve světě, Jan PONĚŠICKÝ, Praha: Triton, 2006, p. 181.

6 Cf. Jan PONĚŠICKÝ, Člověk a jeho postavení ve světě, Praha: Triton, 2006, p. 108.

7 Cf. ibid., p. 22.

8 Jan HÁBL, Pedagogika a metanarace: pro a navzdory postmoderní situaci, in: Pedagogická komunikace v didaktických, sociálních a filozofických souvislostech, Hradec Králové: Gaudeamus, UHK, 2009, p. 33.

9 Cf. Marek FAJFR, Hodnoty jako výzva současné výchovy, in: Hodnoty ve výchově, umění a sportu. Sborník z mezinárodní konference konané na PedF UK Praha, eds. Anna HOGENOVÁ - Naděžda PELCOVÁ, Praha: UK v Praze, PF, 2008, p. 84.

10 Cf. Jan PONĚŠICKÝ, Člověk a jeho postavení ve světě, p. 163.

11 Cf. Marek FAJFR, Hodnoty jako výzva současné výchovy, p. 81.

12 Jan PONĚŠICKÝ, Člověk a jeho postavení ve světě, p. 21.
} 
possession of the world, attempt to know it. The basic, original and common form of human thought is telling stories. As Gregory Bateson has said: "We think in terms of stories." 13 Our world is woven of stories, our own life is a story. The narrative way of communicating and understanding is quite natural for us. A human being normally understands herself within the coordinates of a story. I tell, therefore I am. But how am I? What value orientation determines my story in the context of the world, into whose metanarration I am "thrown" in the Heideggerian way? The transforming power of stories can become a key element of the didactic process in forming the pupil's personality and identity. In the words of Jan Hábl: It is necessary to teach and learn with stories. ${ }^{14}$ The narrative method represents an eminent path of educating to values. By means of it pupils can be taught to seek, find and create their own story. A good story which makes sense.

By means of narration we can participate in being or touch it; "humans are in narration". ${ }^{15}$ As homo narrans we tell stories and thereby order the world. According to Jiří Trávníček narrating a story represents linguistic, social and spatial thinking: "When we think narratively, we move in situations, when we think logically, we must rely on concepts." 16 The author underlines the emphatic and mimetic function of stories and mentions their "heuristic potency": "In stories characters live, act, think and express all their qualities and abilities, and we confront our own existence with them. Stories contain models of acting, which present a real possibility of imitation. They can become a "revelation", which serves the subsequent re-figuration or re-telling of one's own story." ${ }^{17}$ As J. Trávníček states, narration provides us with an opportunity to step out of ourselves and view ourselves as something other. ${ }^{18}$ In recent decades humanities have been dealing with the issue of story. In philosophy, theology, psychology, literary science and cultural anthropology since the second half of the 20th century stories and their effect on humans have become one of the main topics of academic discussion. In the field of theology let us mention narrative theology and its key representatives, such as e.g. G. Lindbeck, H. W. Frei, S. Hauerwas, K. Barth; ${ }^{19}$ of Czech experts M. Altrichter. ${ }^{20}$ In the book The Spell of Story-Telling (2013) Pavel Hošek offers a view of stories from the point of view of hermeneutics, literary theory, depth psychology and a particular religious-cultural tradition where telling stories plays a crucial part. The biblical stories of Old and New Testament and the fictitious narration of belles-lettres "project the world" and carry a particular understanding of human life. The can have a revelatory and truly motivating power. ${ }^{21}$ It is a matter of entering the story and interiorizing the shared narrative image of the world. Stories can have decisive influence on the success of the process of gradual mental maturation of individuals and are used in psychology in so-called narrative psychotherapy. ${ }^{22}$ The point of narrative therapy is moving from a story dominated by a problem to an alternative one. ${ }^{23}$

From the pedagogical point of view the pupil as listener or reader is asked to actively enter the interpretation of the told or read story, to create her own fictitious world, to disclose archetypes

13 Gregory BATESON, Mind and Nature - A Neccesary Unity, Toronto, New York, London, Sidney: Bantam, 1980, p. 14.

14 Jan HÁBL, Učit (se) př́během, Brno: Host, 2013, p. 7.

15 Cf. Daniela HODROVÁ et al., Na cestě ke smyslu. Poetika literárního díla 20. století, Praha: Torst, 2001, p. 785.

16 Jiří TRÁVNÍČEK, Vyprávěj mi něco. Jak si děti osvojuji př́běhy, Praha - Litomyšl: Paseka, 2007, p. 16.

17 Ibid., p. 51.

18 Cf. ibid., p. 52.

19 We recommend e.g. Jaroslav VOKOUN, K rekonstrukci teologie po konci novověku. Postkritický př́stup, Č. Budějovice: Jihočeská univerzita v Č. Budějovicích, 2008.

20 Michal ALTRICHTER, "Duchovni" $a$ „duševni”. Př́spěvek z pohledu teologie narativni, Olomouc: Centrum Aletti, Velehrad: Refugium Velehrad-Roma, 2003.

21 Cf. Pavel HOŠEK, Kouzlo vyprávění, Praha: Návrat domů, 2013, p. 18.

22 Cf. ibid., p. 92.

23 Cf. Jan HÁBL, Učit (se) př́během, Brno: Host, 2013, p. 49 
in characters, to reach self-transcendence. The human task is to perceive, meet, understand and act. ${ }^{24}$ The teacher's task is to awaken pupils from ontological lethargy, to teach them to unlock the story and discover how it relates to being. ${ }^{25}$ The pupil exposed to the power of the story thinks, feels, experiences, identifies herself, receives information, evaluates. She usually grasps her own identity as a story. Understanding oneself therefore means understanding oneself face to face with stories. Through its narrative organization life receives form, order, context, direction and meaning. Paul Ricoeur discussing the phenomenology of narration reaches the conviction that there is some original, intimate mutuality between "to be" and "to be said" ${ }^{26}$

\section{Narration and myth}

Reality has a narrative character and being is a flow action. Human nature as such is rooted in a world of myth. ${ }^{27}$ Myth provided a key to understanding the world where reality was told, where the image of the whole of the world was expressed in the form of stories. ${ }^{28}$ The unity of the world was declared with the word cosmos. The human being was invited to participate in the great drama of life, its mundane everyday course was tightly linked to cosmic events (to the whole of the world, truth and order). Mythical time was the time when the archetypes of humanity were born, it lead humans to ritual behaviour. From the value and ethical point of view mythical thinking is characterised by the transformation of chaos into cosmos, thus confronting the human being with the demand of change. ${ }^{29}$ Myth has value, moral and existential content; its educational significance consists in paradigms (exemplary situations and models of acting). ${ }^{30}$

According to the philosopher Jan Patočka "the mystery of human existence in myth is the 'idea of phronesis', self-reliance. In this the 'guilt of man' consists and it means that man is not guilty; his essential determination is that he is guilt." 31 The educational significance of myth is to lead the human being to the understanding that she herself is an aberration, rupture and ruin, unless she finds the way back under law, order and higher meaning. ${ }^{32}$ The aim of education is to lead the vulnerable yet at the same time brave human being to participate in the world and life and its continuation. Besides obedience to tradition and law, myth also forms wonder with respect to the sacred. ${ }^{33}$

When people stopped believing in the cosmogonic and historical reality of their stories, myth was replaced by philosophy, the world of the reigning logos. According to Mircea Eliade it is "not very probable that a society could fully disengage itself from myth, since the fundamental features of mythical behaviour - exemplar, repetition, dissolution of profane time and union with the time of origins - at least the first two mentioned, are inseparably linked to every human $\operatorname{lot}^{\prime \prime} \cdot{ }^{34}$ Mythical mentality is not a matter of the past, it is still present in a layer of contem-

24 Cf. Zdeněk KRATOCHVÍL, Filosofie živé přirody, Praha: Herrmann a synové, 1994, p. 68.

25 Zdeněk KRATOCHVÍL, Výchova, ž̌ejmost, vědomí, Praha: Herrmann a synové, 1995, p. 55.

26 Paul RICOEUR, Soi-même comme un autre, Paris: Sauil, 1990, p. 69. In October 2015 the publishing house OIKOYMENH is going to publish the Czech translation $O$ sobě samém jako o jiném.

27 Cf. Zdeněk NEUBAUER, Do světa na zkušenou čili O cestách tam a zase zpátky, Praha: Straky na vrbě, 2010, p. 41.

28 Cf. Naděžda PELCOVÁ, Filozofická a pedagogická antropologie, Praha: Karolinum, 2000, p. 17.

29 Cf. Naděžda PELCOVÁ, Vzorce lidství, Praha: Portál, 2010, p. 25.

30 Cf. ibid., p. 21.

31 Jan PATOČKA, Pravda mýtu v Sofoklových dramatech o Labdakovcích, in: Divadelní program Divadla za branou, Sofokles: Oidipus-Antigone,

Praha, 1971, no pagination.

32 Cf. Naděžda PELCOVÁ, Filozofická a pedagogická antropologie, p. 20.

33 Cf. Jan BOUZEK - Zdeněk KRATOCHVÍL, Od mýtu k logu, Praha: Herrmann a synové, 1994, p. 58.

34 Mircea ELIADE, Mýty, sny a mystéria, Praha: OIKOYMENH, 1998, p. 20. 


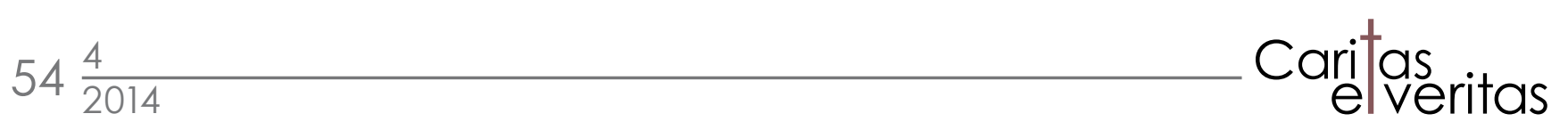

porary experience, understanding and thinking. Contemporary education strives to lead the human being out of the chasm between myth and logos into the sphere of the logos. Construing philosophy and science as a negation of myth becomes the ground of problems. ${ }^{35}$ Through art one can re-awaken to stories and the mysterious spell of mythopoetic images. According to Zdeněk Neubauer, these images and stories disengaged from the world of estranging objectivity can even provide a more truthful and comprehensible approach to the world than scientific factuality. ${ }^{36}$ According to Jan Patočka in every work of art there exists "an emotional dominant functioning as an integrating factor, so that the story has more intensive effect on man than any rational explanation or advice".${ }^{37}$ Contemporary thinking is centred in the left hemisphere of the brain, in rational consideration. The right hemisphere perceives, grasps and expresses reality globally, aesthetically, in values. It is immediately exposed to the effect of symbols, images, stories. ${ }^{38}$ A literary text enables philosophers-hermeneuticians to enter particular stories with the conviction that interpretation as an act of personal encounter with a work of culture is more important than all descriptions, exegeses and analyses. ${ }^{39}$ In Ricoeurian hermeneutics texts create culture, an infinite amount of symbols, an instrument of our existence and desire for being. That is why this philosophy trusts so much in the belles-letters and its stories. ${ }^{40}$

In archaic times mythical stories and narrative materials encoding exemplary models of human activities prevailed. In more advanced cultures we can speak of a holistic shared linguistic image of the world, which also has a narrative structure. It is the so-called great story, the story which according to Pavel Hošek "defines and transmits the shared image of reality". ${ }^{41}$ Metanarration is an artificially created "great story", which wants to bring all individual mythical experience under one roof. It becomes a presupposition of the emergence of a philosophy or "world view" ${ }^{42}$ Jan Hábl reaches the conviction that for centuries metanarrations secured the integrity of human communities and the meaningfulness of experienced reality. According to him every culture was united around a story which was shared and transmitted. ${ }^{43}$ The story gave meaning to everyday events and globally explained reality. According to Pavel Hošek the narrative identity of a community is determined by shared memory and shared hope, by immersion in a jointly recited story. Within a particular cultural or religious tradition the individual significant stories are linked in one holistic "great story" or "great code". ${ }^{44}$ Jan Hábl defines three basic metanarrations - the modern story of the progress of autonomous reason, the pre-modern story of transcendentally rooted history of salvation (Christianity) and the story of the history of the self-development of the spirit (metaphysics).$^{45} \mathrm{~J}$. F. Lyotard in the book The Postmodern Condition (1993) distinguishes metanarrations in three spheres - in the Enlightenment project of human emancipation, in the idealistic teleology of the spirit and in the historicising hermeneutics of meaning. According to him the postmodern period brings an end to great stories. ${ }^{46}$

\footnotetext{
35 Cf. Zdeněk KRATOCHVÍL, Výchova, zřejmost, vědomí, p. 94.

36 Cf. Zdeněk NEUBAUER, Do světa na zkušenou čili O cestách tam a zase zpátky, p. 68.

37 Jan PATOČKA, Umění a čas, Praha: OIKOYMENH, 2004, p. 304.

38 Cf. Zdeněk NEUBAUER, O Sněhurce aneb cesta za smyslem bytí a poznání, p. 13.

39 Cf. Zofia MITOSEKOVÁ, Teorie literatury, Brno: Host, 2010, p. 415.

40 Cf. ibid., p. 418.

41 Pavel HOŠEK, Proměňující moc př́iběhu, Církevní dějiny 5/2010, p. 88.

42 Vladimír MACURA - Alice JEDLIČKOVÁ, Prưvodce po světové literární teorii 20. století, Brno: Host, 2012, p. 493.

43 Cf. Jan HÁBL, Pedagogika a metanarace: pro a navzdory postmoderní situaci, in: Pedagogická komunikace (v didaktických, sociálních a filozofických souvislostech), Sborník z konference PedF UHK, Hradec Králové: Gaudeamus, 2009, p. 31.

44 Pavel HOŠEK, Proměňuící moc př́běhu, p. 90.

45 Cf. @ P Paidagogos, 2012, Jan HÁBL, Aby člověk neupadal v nečlověka aneb o Komenském a smyslu pedagogického počínání (online), at: http://www.paidagogos.net/issues/2013/2/article.php?id=5, accessed February 17, 2014.

46 Jean-François LYOTARD, O postmodernismu. Základní filosofické texty. Praha: Filosofický ústav AV ČR, 1993, p. 143.
} 
According to J. F. Lyotard, together with the paradigmatic change of the intellectual climate there occurs in the postmodern period a crisis of trust in metanarrations, which as a result of a tendency to totalitarianism (dictatorship) had become exclusive interpretations of reality and instruments of power (colonialism of the West, communism of the East). ${ }^{47} \mathrm{~A}$ united and universally valid image mediated by authorities such as scientists, priests, intellectuals and others has been replaced by a plurality of images and linguistic games. ${ }^{48}$

J. F. Lyotard construes postmodern plurality as a perspective counting with diversity. The postmodern society no longer lives for a great whole, a great hero, a great idea. With the assertion of liberal capitalism and the scientific, technical and informational revolution after WWII there comes the collapse of the metanarration and the centralizing focal point of human considerations is thus de-secured. Postmodernity is characterized by the process of deconstruction, examining texts from all possible perspectives. Ascribing a fundamental or final meaning to a text is out of the question. Distrust in metanarration is replaced with a trust in polynarration (multinarration). In his book Between Worlds E Betweenworlds (1997) Václav Bělohradský states that historical worlds have become flared. This philosopher replaces the image of the Platonic cave with a parable of the cold betweenworlds, in which we have "lit fires, by which we sit down, listen and tell stories" ${ }^{49}$ Metaphorically this storytelling by the fire is philosophy. The contemporary world has disintegrated into searching individuals and individual life stories. As if the postmodern time desperately lacked a story of its own.

\section{Narrative paths of educating to values}

The contemporary school is situated in a post-story period, it is a school without a metanarration. As Jan Hábl states in the book To Teach (And Learn) With Stories, in earlier times school was meaningful against the backdrop of either progress or eternity. With postmodernity this meaning has dissolved. School has ceased being a guarantee of the educational-formative role in society, it has ceased being a key means of sharing the metanarration. ${ }^{50}$ The lost metanarration has been replaced by the mass media, the pupil has become a client pragmatically prepared for the demands of the labour market. J. Hábl compares school without a metanarration to theatre devoid of the theatre play. The mythos - the action and the point - is missing. ${ }^{51}$ Such school education leads the pupil to succeed, but does not lead her home - to knowing herself and her meaning in the order of being. The greatest danger is posed by the separation of pupils from their nature, their own humanity and from the experiential character of nature. This defect of humanity is omnipresent in contemporary society. Searching for the natural world was a characteristic feature of the philosophy of Jan Patočka. Zdeněk Kratochvil in his book Education, Evidence, Consciousness (1995) employs the term "denaturation" of nature, humans, society, the world.$^{52} \mathrm{He}$ had already grasped the topic in a marked way in the book Philosophy of Animate Nature (1994): "Denatured substances have the power we want of them, and it is therefore safe to work with them, but nature has been deprived of itself, its intrinsic life and spontaneity." 53 Artificial environment is spreading, human work as a total artefact is creating a new kind of nature. The world is being reified, everything can be degraded into a mere object. Humans

\footnotetext{
47 Cf. ibid., p. 102.

48 Cf. Vladimír MACURA - Alice JEDLIČKOVÁ, Pri̊vodce po světové literární teorii 20. století, p. 493.

49 Václav BĚLOHRADSKÝ, Mezi světy \& mezisvěty: reloaded 2013, Praha: Novela bohemica, 2013, p. 34.

50 Cf. Jan HÁBL, Učit (se) př́během, p. 63.

51 Cf. ibid., p. 65.

52 Cf. Zdeněk KRATOCHVÍL, Výchova, zřejmost, vědomí, p. 149.

53 Zdeněk KRATOCHVÍL, Filosofie živé prírody, p. 19.
} 
experience an arranged and deformed reality, they inhabit an illusive, pseudo-authentic global world. The profanation of the human experience is often accompanied by the feeling of spiritual emptiness. The human being loses the ability to experience wonder, to form a relationship of respect. In the situation of the worldwide value crisis when all is being converted to market value, contemporary school should again find its soul and resist the narrative-less narration of the market and the generally accepted dictate of the mass media.

Postmodern life in a plurality of values must not be a life without obligation. Education in the 21th century is thus confronted with an uneasy task. Science and Christianity face boundless relativism on the one hand and extreme fundamentalism and sectarianism on the other. The postmodern plurality of confession and spirituality, blending of worlds and cultures, the non-existence of a centre of the hierarchic ordering of society and the image of the human being closed in the postmodern cave with her subject-object thinking, all that presents a challenge to contemporary pedagogy. What paths should we take?

One of the paths of the humanizing effort of contemporary pedagogy is the rehabilitation of narrativity in the didactic process. In his book To Teach (And Learn) With Stories (2013) Jan Hábl proposes introducing so-called didactic narrativization - storification. ${ }^{54}$ This methodological principle consists in using stories in pedagogical practice on the psychological and philosophical level within particular field didactics. At the same time the author calls for the rehabilitation of metanarrative discourse: "Contemporary pedagogy ought to seek such metanarration that would make all partial didactic narrations authentic and legitimate." 55 According to him the school does not merely communicate "neutral" facts, but also their interpretative frames. It organizes partial information and events into a large "plot", which determines their meaning - not only in the hermeneutic sense, but also in ethical sense. ${ }^{56}$ According to Marek Fajfr education can be based in the continual telling of stories as "stories in the sense of non-enclosed texts, in the sense of a tale which is constantly being told in thousands of variations" ${ }^{57}$

In his view the dynamic character of stories should reflect the functional value of contemporary education expressed in terms of key competencies. Little story-telling takes place in contemporary schools, the transmission of items of knowledge prevails. In this context Zdeněk Kratochvíl recalls Plato's ironic statement about inserting knowledge into a passive soul as "inserting sight into blind eyes". ${ }^{58}$ By means of stories the school should awaken the pupil's soul, ignite fire in it, so that the pupil learns "to live out of her source", live in the authenticity of her being. It should be a real space of living encounter face to face with the teacher and the text in pure authentic dialogue in a shared seeking of questions and answers. The basis of dialogue is at the same time the need for self-reflection "with the eyes of the other". The teacher with her life story reflected in her value orientation and the complexity of her personality, in the unity of words and acts, in the spirit of the classical "Exempla trahunt", plays a key part in the educational process. In contemporary schooling it is necessary to reflect the plurality of being and at the same time a sense for non-categorizable human values - experiential knowledge and selfless love. ${ }^{59}$

\footnotetext{
54 Cf. Jan HÁBL, Učit (se) př́během, p. 67.

55 Ibid., p. 69.

56 Cf. ibid., p. 68.

57 Marek FAJFR, Hodnoty jako výzva současné výchovy, p. 86.

58 PLATÓN, Ústava VII, Praha: Svoboda, p. 518.

59 Cf. Zdeněk KRATOCHVÍL, Výchova, zřejmost, vědomí, p. 12
} 
Jan Hábl's call for a search for a metanarration for contemporary postmodern pedagogy of the post-educational period is not isolated. The whole educational sector needs to define its identity anew. ${ }^{60}$ Despite much effort at pedagogical humanization of schooling, the school still remains "essentially functionalist" and fails to cultivate "the whole human" ${ }^{61}$ Education should develop the ability to think logically and at the same time to perceive the myth. Basically it is a matter of orienting the mind to its source, to the idea of the good, by means of understanding the present as a gate to eternity or to an enlightened future. In the first case it is an invitation to return to the mysterian roots of faith, to conceiving the human being as imago Dei in traditional biblical narration, as a being created for an essential relationship with God. With her character the human being is to reflect the character of God, i.e., the greatest possible thinkable good. ${ }^{62}$ Metanarration carrying the Christ-like story of sacrificial love flows into the transcendentally rooted history of salvation. It means accepting the Gospel as good news and the Decalogue as the Christian ethical code. In the latter case it is necessary to assume that the world is meaningful and ordered, that humans are granted a place in this world and the course of the world is directed to progress. A future presupposes a value orientation on sustainable life, on the ability of humans to order the broken world. At present the most pressing is "moral progress", which consists in the spreading of sympathy. ${ }^{63}$ Values are the pillars of our life. Every human being seeks an ethical ideal for support and constructs it in the story of her life. ${ }^{64}$ According to Jan Sokol a human being must "glimpse the value, set out after it and persevere - and all that alone". ${ }^{65}$ At the same time she is "weaving a shared story" with the others. The will to do the good, which links the two abovementioned metanarrations, royally crowns the life of those who carry it.

While interceding to seek a great story Jan Hábl calls to penance, courage and faith in seeking a secure point on which to construct the pedagogical house. ${ }^{66}$ Without the ideal it is not possible to construct the real. Life is a seeking, being on the way, relationality; the world is a natural space of self-transformation. Postmodernism does not make any claims on the future, it prescribes nothing to the present. We have stated that the postmodern period seems to lack a story of its own. But there is no narration without metanarration. Every little story is told in the context of a great story. Thus even the postmodern story, which tells of the distrust in any story, is in fact a meta-story. The meaning of contemporary atheism in which the deviation from God at the personal level is parallel to another form of atheism - estrangement from oneself - consists in overcoming it. We share the view of Zdeněk Neubauer that the meaning of postmodernism is revealed in its incorporation in the shared story of the history of salvation. ${ }^{67}$

The task of educating to values (value pedagogy) is to cultivate a sense for values, to teach to prefer eternal values to temporal ones, to live as fully as one can. The philosopher Jan Patočka defined the goal of life as "life itself, clarity, approaching oneself, the naked situation of being, living in authenticity as opposed to the dispersion of the 'public anonymous', it is a matter of allowing oneself to be addressed by humans and things, of revelation". 68 Everything around

60 Cf. (C) Paidagogos, 2012, Jan HÁBL, Aby člověk neupadal v nečlověka aneb o Komenském a smyslu pedagogického počínání.

61 Jan HÁBL, Lekce z lidskosti: Antropologické inspirace z díla Jana Amose Komenského, Pedagogická orientace 1/2010, p. 6.

62 Cf. ibid., p. 10.

63 Cf. Jan PONĚŠICKÝ, Člověk a jeho postavení ve světě, p. 97.

64 Cf. Miloslava BLAŽKOVÁ, Odysseovy cesty od Homéra k postmoderně, in: Éthos ve výchově, umění a sportu, Naděžda PELCOVÁ - Anna HOGENOVÁ, Praha: PedF UK 2009, p. 189.

65 Jan SOKOL, Slovník filosofických pojmů, Praha: Vyšehrad, 1998, p. 179.

66 Cf. Jan HÁBL, Učit (se) př́během, p. 70.

67 Cf. Zdeněk NEUBAUER, O počátku, cestě a znamení časů, p. 223.

68 Jan PATOČKA, Úvod do fenomenologické filozofie, Praha: OIKOYMENH, 2003, p. 160. 
us has ${ }^{69}$ epiphanic value and perhaps precisely the contemporary postmodern time of boundless plurality is the right time for a revelation of the Truth and for a subsequent paradigmatic change, a breakthrough transformation of society. ${ }^{70}$ In the bosom of the postmodern society of secularized values there grows a desire for something absolute and noble. The highest triad of the values of Truth, the Good and Beauty poses a perennial challenge to humans.

\section{Conclusion}

Schooling should not primarily be concerned with what pupils will take out of school (facts, skills, competencies), but what they will become. It is a matter of physical, psychological, social and spiritual integrity of the unity of their existence, a matter of learning to recollect themselves (logos) and recollect their own logos with the logos of the polis and cosmos, i.e., with the logos of the Whole. ${ }^{71}$ The teacher should allow herself be permeated with the contradictoriness of the time and have the courage to attempt a synthesis. To select the material for instruction with respect to developing the value orientation of pupils, to educate with values to values. Pupils should seek answers to serious existential and ethical questions by means of art. Art presents an eminent path to oneself, addresses the soul and its powers. In the words of Zdeněk Neubauer: "It awakens, addresses and brings to life the various powers of the human psyche; it speaks into the world we inhabit, speaks in stories that never happened, of which we are nevertheless a part." 72

According to Ivo T. Budil telling stories as an essentially human phenomenon is an anthropological constant of human existence. ${ }^{73}$ By means of narration the identity of human beings is formed. Emotion, image and word are always in between narration and true being. ${ }^{74}$ It is said that truth clothed in a story passes through all doors. A reflection of the Gospel permeates all great art. And where we discover the sacred in us, there we begin to be. ${ }^{75}$ The world reflected by the teacher through the lens of stories helps to set human matters straight and transcendentally root the humanity of pupils. The story as an immediate imprint of life opens the third eye for transcendent values and brings us nearer to the Socratic ideal of eternal seeking for truth, the good and beauty. Let us therefore tell stories to our children and pupils. They are creative acts, by means of which we create the world. It is the right key to opening the mystery of life and human existence. It leads to the essence of the soul, to the house of one's heart. "And the heart has its reasons, of which reason knows nothing..."76

\section{A Paean to Narration, or Narrative Paths of Educating to Values}

Abstract The paper deals with the narrative method as a possible way of educating to values. The story and its effect on humans has since the second half of the 20th century been a major discussion topic of philosophy, theology, psychology, literary theory and cultural anthropology. From the pedagogical point of view the study emphasizes the reader's involved entering the story in the spirit of so-called rehabilita-

69 Cf. Jan PONĚŠICKÝ, Člověk a jeho postavení ve světě, p. 83.

70 Cf. Zdeněk NEUBAUER, O počátku, cestě a znamení časů, p. 237.

71 Cf. Jan PONĚŠICKÝ, Člověk a jeho postavení ve světě, p. 204.

72 Zdeněk NEUBAUER, Smysl a svět, Praha: Nadace Dagmar a Václava Havlových Vize 97, 2001, p. 92.

73 Cf. Ivo T. BUDIL, Mýtus, jazyk a kulturní antropologie, Praha: Triton, 2003, p. 277.

74 Cf. Martin BUBER, Já a Ty, Praha: Kalich, 2005, p. 28.

75 Cf. Daniela HODROVÁ, Chvála schoulení (Eseje z poetiky pomíjivosti), Praha: Malvern, 2011, p. 167.

76 Blaise PASCAL, Myšlenky, LXIX, Praha: Mladá fronta, 1973, p. 22. 
tion of narration in the didactic process. Physical, psychological, social and spiritual integrity of the unity of an individual existence can be attained by means of stories which allow for educational effect even in the postmodern period.

Keywords narrativity; narrativization; story-telling; story; postmodern society; educating to values 